\title{
The Framework of the Implementation of Entrepreneurship Elements in Malaysian Polytechnic
}

\author{
Hanim Zainal*, Khata Jabor, Idris Mohammed Abdullahi \\ School of Education, University of Technology Malaysia, Malaysia
}

Received May 16, 2020; Revised June 22, 2020; Accepted July 20, 2020

\section{Cite This Paper in the following Citation Styles}

(a): [1] Hanim Zainal, Khata Jabor, Idris Mohammed Abdullahi, "The Framework of the Implementation of Entrepreneurship Elements in Malaysian Polytechnic," Universal Journal of Educational Research, Vol. 8, No. 9, pp. 3970 - 3980, 2020. DOI: 10.13189/ujer.2020.080922.

(b): Hanim Zainal, Khata Jabor, Idris Mohammed Abdullahi (2020). The Framework of the Implementation of Entrepreneurship Elements in Malaysian Polytechnic. Universal Journal of Educational Research, 8(9), 3970 - 3980. DOI: 10.13189/ujer.2020.080922.

Copyright $@ 2020$ by authors, all rights reserved. Authors agree that this article remains permanently open access under the terms of the Creative Commons Attribution License 4.0 International License

\begin{abstract}
Entrepreneurial education is an important strategy in producing entrepreneurial-minded students [1]. This entrepreneurial spirit needs to be nurtured through good education structure. Furthermore, education can play a key role in shaping the culture of entrepreneurship among students. Therefore, education that focuses on entrepreneurship concepts for students must be given proper attention. The need for knowledge in the field of entrepreneurship among polytechnic lecturers is very much needed as lecturers should be knowledgeable and must be prepared before teaching the students. This study aims to draw on the application of entrepreneurial elements among polytechnic lecturers in Malaysia. Data analysis involves the process of analyzing qualitative data using Nvivo software. There were 10 lecturers who lectured entrepreneur's subject being selected in the interviews including lecturers from Sultanah Bahiyah Polytechnic, Syed Syed Sirajuddin Polytechnic, Sultan Abdul Halim Muadzam Shah Polytechnic, Jelly Polytechnic, Kota Bharu Polytechnic, Mersing Polytechnic and Sultan Ibrahim Polytechnic. In that regard, the results of this study can serve as a source of reference especially to lecturers who wish to learn something beyond their area of expertise using this entrepreneurial application method. Lecturers can explore new knowledge by applying and practicing various methods of applying entrepreneurship. Thus, the process of applying for entrepreneurship will be more efficient, effective and usable during the teaching and learning process both in college and beyond college.
\end{abstract}

Keywords Framework, Entrepreneurship, Practice,
Knowledge, Skill, Environment

\section{Introduction}

Entrepreneurship education is a lifelong education where knowledge, skills and entrepreneurial values are gained through formal or informal learning [2]. In the context of this study, entrepreneurship education is described as a process for acquiring entrepreneurship knowledge, skills and practices among lecturers. Elements of entrepreneurial knowledge, skills and practices through formal learning in the lecturers' education curriculum (major and minor) and off-the-classroom learning through co-curriculum activities that lead to entrepreneurship.

The study was about exposure to the elements of entrepreneurship. There are also theories outlined in this study that include general entrepreneurship theory. Entrepreneurship is a process, target and environment that affects the opportunity to create and provide services through the process of identification, exploitation and evaluation [3]. Thus [4] states that this condition requires specific desires, motivations and skills. Therefore, this study aims to formulate a framework for the application of entrepreneurial elements that serves as a reference point for those who are called entrepreneurship lecturers.

The objectives of this study are to:

1. Identify elements of entrepreneurship knowledge among polytechnic lecturers. 
2. Identify elements of entrepreneurship practice among lecturers in polytechnics.

3. Identify elements of entrepreneurial skills among lecturers in polytechnics.

4. Identify environmental elements in polytechnics in the field of entrepreneurship.

5. Provide the framework for the application of entrepreneurial elements in Malaysian polytechnics.

\subsection{Entrepreneurial Element Dimension}

\subsubsection{Entrepreneurship Knowledge among Lecturers}

Knowledge in entrepreneurship is an informative piece about entrepreneurship concepts and items that are fundamental to the business process. In addition, this knowledge-related information is also accessible when circumstances require [5]. It was also a gift that can be seen from an activity or an individual's experiences [15]. Besides that, it also can be generated by attending entrepreneurship seminar programs or talks [16]. Knowledge also about modernity to expand new knowledge from time to time other than conventional education [17]. Fresh knowledge can be gained from past experience to be a lesson for the future time.

Knowledge is about education investment to everyone through training that can enhance knowledge, develop ability and lastly can manage a good quality of living. For lecturers, knowing the latest information on the field of entrepreneurship can enhance knowledge towards entrepreneurship worlds. Various methods can be obtained related to entrepreneurial information such as exploring the internet, reading books and even watching television.

This era of global technological sophistication and unrestricted globalization makes information systems in the field of entrepreneurship accessible. [23] define entrepreneurial knowledge as an observable ability of an individual's actions or behaviors. Whereas [24] explains that knowledge is not just about knowing the relevance of an object and mentioning it but that the individual has to interpret exactly what the object knows.

In addition, the level of knowledge is based on the experience gained and utilized at the appropriate time according to their ability to plan the knowledge. Shahrin and Siti Asmah [25] define knowledge not only as a formal education but also as an entrepreneurial program, transforming past experience into new knowledge. Researchers also argue that this entrepreneurial knowledge is acquired specifically through formal education or through existing experience. Every lecturer needs to have this entrepreneurial knowledge to enable them to justify when applying the entrepreneurial element to their students.

However, according to Siti Normala [26] the knowledge available to educators is not yet satisfactory especially in the search for an era of education that is changing every day. This is because the level of knowledge of the faculty does not provide any guarantee in the application of entrepreneurship to the students as there are constraints on the challenges that must be faced in the entrepreneurship application fluid. This can be seen through the lack of confidence and the lack of confidence among educators to apply entrepreneurship after learning about the growth and risks in the business arena.

[27] states that educators lack exposure to the latest and greatest knowledge and that educators cannot feel sufficient to have existing knowledge. Educators must therefore increase their knowledge to keep pace with the educational system that has changed over time following the leadership of the national administration. Moreover, according to [28] found that educators have knowledge of entrepreneurship but they still have the ability to communicate the subject matter. It is not impossible for technical educators who are not as well exposed in this field of entrepreneurship but tend to be in their own technical fields.

Besides that, knowledge is about a fact of information that can get through experience or education theoretically or practically that we want to know something else. Knowledge is also in long-term memory that can store a variety of relevant information.

Furthermore, educators are more confident and passionate to apply knowledge related to entrepreneurship through their own entrepreneurial knowledge even if it is not related to their technical field. The current trend of modernization has required educators to diversify existing knowledge and add new knowledge in applying the ever-changing educational system.

In conclusion, it is the duty of lecturers to always seek knowledge of entrepreneurship in order to keep up with the latest technological advances and explosion of the business arena. One way to increase entrepreneurial knowledge in managing a business or education can be through reading, attending an entrepreneurship seminar, consulting with experts and so on.

\subsubsection{Entrepreneurship Practice among the Lecturers}

Practice is an ongoing trait in which a person reacts positively if something he or she is interested in. If it's negative, it feels like a burden to someone.

A practice is about the learning process among lecturers in the field of entrepreneurship such as lessons that should be respected in the learning process and lastly can motivate themselves to teach and implement activities with students. Every practice applied through entrepreneurial activities can indirectly motivate the lecturers.

The practice that is often done by an educator in the learning and teaching process covers aspects of students learning, examining student work, assigning students or assignments based on student achievement levels, as well as selecting items that need to be evaluated in the teaching and learning process and ultimately encourage students to learn. 
For lecturers that have a high practice level in entrepreneurship task can make themself more confident and able to implement activities effectively. Accordingly to [18], interest is a factor that becomes a habit of a person in doing their activities. Lecturers with positive vibes are mostly interested in what they are doing. Meanwhile, lecturers who have no interest will reflect in different ways [19]. If there are lecturers who are interested but have limited abilities that is a medium, they could extend deep interest and try harder to achieve a level that they might be. So that, the lecturers in positive and confident can directly affect themselves to be practical and committed with their teaching or doing in entrepreneurial activities.

In addition, educators who are interested in their teaching, have a positive attitude toward improving their academic performance and are confident in what they do and will indirectly reflect their patient, committed, approachable and friendly nature.

In addition, there are five practices practiced in entrepreneurial education namely, imparting entrepreneurial knowledge and skills, developing entrepreneurial skills, cultivating entrepreneurial traits, demonstrating entrepreneurial nature and finally applying cultural elements in entrepreneurship to students. Lecturers also need to play an important role in students' self-awareness related to entrepreneurial skills such as student involvement in challenging and experience-based learning environments [29]. Lecturer practice in entrepreneurship will provide insights into business in terms of meaning, structure and relationships with other sectors of the economy and society [30]; raising awareness of the commercial world and developing personal attributes [31]; and ensure that the necessary knowledge is transferred from the education system to the industry [32].

Thus, educators who are interested in their teaching, have a positive attitude toward improving their academic performance and are confident in what they do and will indirectly reflect their patient, committed, approachable and friendly nature

\subsubsection{Entrepreneurial Skills among Lecturers}

Entrepreneurial skills refer to the method of conducting certain activities in entrepreneurship. Although entrepreneurial activities are based on the knowledge they have, [6] states that other skills and knowledge should be learned and refined to reinforce entrepreneurship such as creative, innovative and so on. Entrepreneurship skills can be measured through academic achievement or work without being influenced by attitude and motivation [7]. As a result of the literature review, there are four aspects of entrepreneurship skills in general namely technical skills, human skills, conceptual skills [8]. Entrepreneurial skills help individuals to act more effectively when faced with competition and changes that occur from various angles that affect business activities. As such, the skills presented are broadly encompassing various entrepreneurial activities, a qualitative study conducted to identify the elements of entrepreneurial skills in the application of entrepreneurship in Malaysian polytechnics.

Entrepreneurial skills are based on the ability to explore opportunities and increase awareness of innovation, risks and creativity in business and entrepreneurship-related activities. In addition, entrepreneurship activities are also closely linked to the subsequent adoption of students of business culture [33]. Furthermore, entrepreneurial skills can also be interpreted as his behavior or his actions as an entrepreneur [34].

In addition, [35] stated that the change in the positive attitude of the teaching staff in implementing the teaching and teaching occurred as required by the National Philosophy of Education. In undertaking various entrepreneurial activities, an educators need to strengthen their entrepreneurial skills in order to be successful entrepreneurial activities [36].

Technical skills refer to the ability to apply specific knowledge and techniques in a particular field. Among the key technical skills in applying entrepreneurship that lecturer respondents have shared in interviews are communication networks, the use of technology in business operations, marketing of business products and finance for business costs. All of these skills are usually acquired through formal education or through work experience.

In addition, human skills refer to a person's ability to understand other people's behaviors and to influence their leadership when faced with certain situations. In a qualitative study conducted, communication skills and interpersonal skills are elements of the skills used in entrepreneurship in Malaysian polytechnics. These skills can be acquired through proactive education such as engaging in discussions and conferences [9].

Conceptual skills refer to the ability to coordinate and integrate business activities into the realm of vision. According to [6], management skills are intended to expand knowledge in entrepreneurship and build the business spirit needed. Other examples of management skills are financial management, marketing management and business planning management [8].

Thus entrepreneurship skills are seen as more focused on common skills, which are skills that are often acquired when you are an entrepreneur. Each of these skills with motivation will be stronger as a driving force in the success of the business conducted by the entrepreneurial lecturer.

\subsubsection{Entrepreneurship Environment among Lecturers}

The environment is a physical element or an ecosystem that influences every entrepreneurial development. Collaboration and support from stakeholders also created the desired environment with the ability of educators and students to work hard to incorporate entrepreneurial elements in polytechnics. Therefore, the provision of a conducive and friendly environment can foster 
entrepreneurial intentions among lecturers [10].

Strategic thrust of the Entrepreneurship Development Policy Institutions of Higher Education has set out to provide an environment and ecosystem that is conducive to entrepreneurial development. The entrepreneurial environment is a combination of factors that play a role in entrepreneurship development. It refers to the availability of support and support services that facilitate the start-up process for entrepreneurship. Common environmental conditions affecting entrepreneurship are related to support infrastructure and provision of training and support services in entrepreneurship. Infrastructure is about layouts that involve management's leadership strategies as an example of educational institutions in order to create a quality environment and emphasize creativity. Additionally, the entrepreneurial support element is about programs and initiatives created to help entrepreneurs when they need it most. It involves services such as organizations and financial networks and others in the field of entrepreneurship in particular.

[20] describes that learning environment is referring to the social, psychological and pedagogical contexts in which teaching and learning sessions take place that have an impact on an individual's behavior and achievement. Whereas [21] describes the environment as family, friends, community, technology facility, institutional environment which is an identified element influencing an individual's development. Therefore, effective educators in teaching and learning management can produce competent and responsible individuals.

Infrastructure is also an element of the environment that influences the application of entrepreneurship to a higher education institution. According to [22], the campus infrastructure is influential in sparking entrepreneurial interest among lecturers and students. Therefore, the polytechnic environment is an important element in influencing the application of entrepreneurship in polytechnics.

In addition, the provision of a conducive learning environment has enabled more entrepreneurs to graduate [37]. Providing a good and conducive environment especially in public universities is a key goal of the Ministry of Higher Education Malaysia. This is also supported by [38] who states that conducive environments will find opportunities that eventually lead to the opening of new ventures. In fact, Buang [39] also argues that environmental factors are a catalyst for business idea selection and a source of business ideas in their research based on entrepreneurial thinking models. Thus, the polytechnic environment is an important element in the implementation of entrepreneurship.

Thus the entrepreneurial environment which should be flexible should inspire lecturers to be more enthusiastic about applying the entrepreneurial element to students in
Malaysian polytechnics.

\section{Materials and Methods}

\subsection{Sample}

In this qualitative study, the researchers chose to conduct data collection using strata random sampling technique. According to [11], a randomized-sample random sampling technique is a technique that is applied based on a population that does not exhibit characteristic imbalances in a sample. [12] Described the design of stratified random sampling is probably an effective method. While the same number of samples will give more information. In fact, the selection of the same sample is most appropriate when the population strata are too small and too large. Therefore, 10 entrepreneurs of lecturers from Sultanah Bahiyah Polytechnic, Syed Syed Sirajuddin Polytechnic, Sultan Abdul Halim Muadzam Shah Polytechnic, Jeli Polytechnic, Kota Bharu Polytechnic, Mersing Polytechnic and Ibrahim Sultan Polytechnic were randomly selected for interview for this study.

\subsubsection{Instrument of study}

In this study, the researchers used interview methods to obtain data from respondents. Interviews can be structured, semi-structured or non-structured [13]. Interview data collection aims to understand the issues, processes and situations under investigation. The "open-ended" question was read directly in front of the respondents. This allows researchers to build close relationships and trust with the respondents that can increase the motivation for the respondents to continue the interview and generate more honest and open answers [14]. Researchers made voice recordings of all interview sessions to produce transcriptions and subsequently analyzed. For the purposes of this study, the interviews were conducted in the form of open-ended questions based on the results of the document review.

\section{Findings}

\subsection{Element of Practice}

According to the analysis, overall respondents of the interview responded positively to entrepreneurial practices in applying the entrepreneurship and the variety of opinions and views received by the researchers in the interview. Table 1 below provides a brief overview of the results of the interview conducted in conjunction with the lecturers in polytechnics to identify elements of entrepreneurship practice in the field of entrepreneurship. 
Table 1. Summary of interview results for practice elements

\begin{tabular}{|c|c|c|c|c|c|c|c|c|c|c|}
\hline \multirow{2}{*}{ Themes } & \multicolumn{10}{|c|}{ Lecturer Respondent } \\
\hline & P1 & P2 & P3 & P4 & P5 & P6 & P7 & P8 & P9 & P10 \\
\hline Experience & $\sqrt{ }$ & & & & $\sqrt{ }$ & & $\sqrt{ }$ & $\sqrt{ }$ & & $\sqrt{ }$ \\
\hline Interest & & $\sqrt{ }$ & & & & & & & $\sqrt{ }$ & \\
\hline Communication Network & & & $\sqrt{ }$ & & & & & & & \\
\hline Teaching Learning & & & & $\sqrt{ }$ & & & & & & \\
\hline Muamalah & & & & & & $\sqrt{ }$ & & & & \\
\hline Motivation & $\sqrt{ }$ & & $\sqrt{ }$ & $\sqrt{ }$ & $\sqrt{ }$ & $\sqrt{ }$ & $\sqrt{ }$ & $\sqrt{ }$ & $\sqrt{ }$ & $\sqrt{ }$ \\
\hline Conflict & & $\sqrt{ }$ & & & & & $\sqrt{ }$ & $\sqrt{ }$ & $\sqrt{ }$ & $\sqrt{ }$ \\
\hline Management & $\sqrt{ }$ & & & $\sqrt{ }$ & & & & & & \\
\hline Positive & & $\sqrt{ }$ & & & & & & & & \\
\hline Enhancement & & & $\sqrt{ }$ & & $\sqrt{ }$ & $\sqrt{ }$ & $\sqrt{ }$ & $\sqrt{ }$ & $\sqrt{ }$ & $\sqrt{ }$ \\
\hline
\end{tabular}

Below is the choice of answer from lecturer respondent's no. 5 and no. 8 which contains the majority of the required practice elements.

Quote from lecturer respondent no.5, "Best practices. always be attentive, focused and not easily discouraged. Then be trustworthy ... trustworthy and honest.. because they cannot be invented, they think they are smart... just to follow others.. as a lecturer .. that teach the subject of entrepreneurship .. they need to be involved in entrepreneurship .. they need to be an entrepreneur .. even if the target is to be an educator .. but in itself there is an aspect of entrepreneurship .. if possible around 80-90 percent .. then it can deliver the knowledge to the students effectively..".

Quote from lecturer respondent no.8, "The best practice is that lecturers must be involved in business in particular .. that experience they must have .. this practice also comes from the knowledge and skills that lecturers have .. as a lecturer they should be the best mentors to the students ..”.

The majority of lecturer respondents found that motivation from their own business or personal helped many lecturers in delivering practical theoretical knowledge to students. This allows lecturers to make the business a way to learn the basics of business knowledge and can then share that business experience with polytechnic students.

\subsection{Elements of Knowledge}

According to the analysis, overall respondents of the interview responded positively to entrepreneurial knowledge in the application of entrepreneurship and the variety of opinions and views received by the researchers in the interview. Table 2 provides a brief overview of the results of the interview conducted in conjunction with the lecturers in polytechnics to identify elements of entrepreneurial knowledge in the application of entrepreneurship.

Below is a selection of lecturer respondent no.2 and no.10 which contains the majority of the required knowledge elements.

Quote of lecturer respondent no.2, "In my opinion, the element of knowledge.. the element ... that the lecturer needs to have ... what is the basic to do a business ... how to do a marketing.. How to market the products. there is a needed on a little bit of knowledge on bookkeeping ... even before this I had called my friends who teach at other polytechnics to teach our students about bookkeeping that in the field of commerce.... well it's three to four times we call lecturers from other polytechnics to help us have students create accounts .. that's it .. ".

Quote from lecturer respondent no.10, "Knowledge of marketing ... online business .. Most of the lecturers who teach the subject of entrepreneurship are not from entrepreneurial background.. so they attended a course to gain their knowledge for their students ..".

The majority of respondents among the lecturers stated that business fundamentals are an essential part of the knowledge that every entrepreneurial lecturer should have. Indeed, basic business knowledge has greatly assisted the lecturer in controlling all activities in the field of entrepreneurship and indirectly enabled the culture of entrepreneurship among polytechnic residents. 
Table 2. Summary of interview results for knowledge elements

\begin{tabular}{|c|c|c|c|c|c|c|c|c|c|c|}
\hline \multirow{2}{*}{ Themes } & \multicolumn{10}{|c|}{ Lecturer Respondent } \\
\hline & P1 & $\mathrm{P} 2$ & P3 & P4 & P5 & P6 & P7 & P8 & P9 & $\mathrm{P} 10$ \\
\hline Direction & $\sqrt{ }$ & & & & & & & & & \\
\hline Basic of Business & & $\sqrt{ }$ & $\sqrt{ }$ & $\sqrt{ }$ & $\sqrt{ }$ & $\sqrt{ }$ & $\sqrt{ }$ & $\sqrt{ }$ & $\sqrt{ }$ & $\sqrt{ }$ \\
\hline Polytechnic Activities & $\sqrt{ }$ & $\sqrt{ }$ & & $\sqrt{ }$ & $\sqrt{ }$ & & $\sqrt{ }$ & & & $\sqrt{ }$ \\
\hline Individual & & & $\sqrt{ }$ & & & $\sqrt{ }$ & & $\sqrt{ }$ & $\sqrt{ }$ & \\
\hline Training of Trainers & $\sqrt{ }$ & $\sqrt{ }$ & & & $\sqrt{ }$ & & $\sqrt{ }$ & $\sqrt{ }$ & & $\sqrt{ }$ \\
\hline Digital Entrepreneurship & & $\sqrt{ }$ & & & & & & & & \\
\hline Workshop Datuk Azizan Osman & & & $\sqrt{ }$ & & & & & & & \\
\hline $\begin{array}{c}\text { Campus Entrepreneurs } \\
\text { Movement }\end{array}$ & & & & $\sqrt{ }$ & & & & & & \\
\hline Chambers of Commerce & & & & & $\sqrt{ }$ & & & & & \\
\hline $\begin{array}{l}\text { Malaysian Development } \\
\text { Entrepreneurship Center }\end{array}$ & & & & & & $\sqrt{ }$ & & & & \\
\hline $\begin{array}{l}\text { Entrepreneurship Learning } \\
\text { Programme }\end{array}$ & & & & & & & $\sqrt{ }$ & $\sqrt{ }$ & & \\
\hline Global E-commerce Talent & & & & & & & & $\sqrt{ }$ & & \\
\hline Workshop Facebook Ad & & & & & & & & & $\sqrt{ }$ & \\
\hline
\end{tabular}

\subsection{Elements of Skill}

According to the analysis, overall respondents of the interview responded positively to entrepreneurial skills in applying entrepreneurship and the variety of opinions and views received by the researchers in the interview. Table 3 below provides a brief overview of the results of the interview conducted in conjunction with the lecturers in polytechnics to identify elements of entrepreneurial skills in entrepreneurship application.

Table 3. Summary of interview results for skill elements

\begin{tabular}{|c|c|c|c|c|c|c|c|c|c|c|}
\hline \multirow{2}{*}{ Themes } & \multicolumn{10}{|c|}{ Lecturer Respondent } \\
\hline & $\mathrm{P} 1$ & $\mathrm{P} 2$ & P3 & P4 & P5 & P6 & P7 & P8 & P9 & $\mathrm{P} 10$ \\
\hline Confident & $\sqrt{ }$ & & & & & & & & & \\
\hline Communication & & $\sqrt{ }$ & & & & & $\sqrt{ }$ & & & $\sqrt{ }$ \\
\hline Public Relation & & & $\sqrt{ }$ & & & & & & & \\
\hline Brave & & & & $\sqrt{ }$ & & & & & & \\
\hline Interpersonal & & & & & $\sqrt{ }$ & & & & & \\
\hline Technology & & & & & & $\sqrt{ }$ & & $\sqrt{ }$ & $\sqrt{ }$ & \\
\hline Marketing & & & & & & & $\sqrt{ }$ & $\sqrt{ }$ & & \\
\hline Financial & & & & & & & $\sqrt{ }$ & & & \\
\hline Class & $\sqrt{ }$ & & & & & & & & & \\
\hline Entrepreneur Guidance & $\sqrt{ }$ & & & & & & & $\sqrt{ }$ & & \\
\hline Democracy & & $\sqrt{ }$ & & & & & & & & \\
\hline Sales Activities & & & $\sqrt{ }$ & & $\sqrt{ }$ & $\sqrt{ }$ & $\sqrt{ }$ & & $\sqrt{ }$ & $\sqrt{ }$ \\
\hline Online Network & & & & $\sqrt{ }$ & & & & & & \\
\hline Paper Work & $\sqrt{ }$ & & & & & $\sqrt{ }$ & $\sqrt{ }$ & & $\sqrt{ }$ & \\
\hline Guide & & $\sqrt{ }$ & $\sqrt{ }$ & $\sqrt{ }$ & $\sqrt{ }$ & & & $\sqrt{ }$ & & $\sqrt{ }$ \\
\hline
\end{tabular}


Below is the choice of answer from lecturer respondent's no.1, no.3, no.4, no.5, no.7 and no.8, no.9 which contains the majority of the required skill elements.

Quote from lecture respondent no.1, "The variety of methods, one is the learning in the classroom in theory. Then practically this student will be mentored by their mentor to conduct the activities. The next is through the guidance of real entrepreneurs. We have collaborations with SMEs for example. We unite our students with them. It is also a technique of teaching and exposing our students to the outside world, we enter large exhibitions involving ... we sit side by side with real entrepreneurs. That is a very effective method for me that can transform our students from one who is quiet to one who can sell things".

Quote from respondent lecturer no.3, "For me, that element of public relations was ... when we were able to build relationships between us as entrepreneurs and the people around us as consumers ... which is why I see the importance of entrepreneurship skills".

Quote from respondent lecturer no.4, "The key element for me in entrepreneurship is the ability to convince others. Sometimes theoretically we have learned a lot but we just can't seem to convince anyone about our product. If we do not have any knowledge but we can be sure of convincing others about our product, that is a skill that ... your knowledge and skills are different. That is a skill that any entrepreneur or lecturer should have".

Quote from lecturer respondent no.5, "This skill depends on the lecturer.. but from our point of view with the student.. students want to see how we handle with each of these issues ... we need to have interpersonal skills ..".

Quote from lecturer respondent no.7, "The most important thing in terms of marketing ..the product is how good it is even if we don't know the marketing, it's a problem .. Lecturers also need marketing knowledge .. financial skills are also important .. for engineering lecturers. the important thing is that they need to know the basics of accounting .. credit debit .. cash flow .. cash out .. make a note .. simple things .. basic is important .. then their communication skills .. we just keep online .. offline should also be made .. to deal with the public .. ".

Quote from lecture respondent no.8, "Digital entrepreneurship skills. Obtainable by going to courses and sharing sessions .. basic techniques in entrepreneurship .. example like BMC.... Business Model Canvas...nowadays digital business model.. we need to understand the current situation .. this business is global .. Copywriting technique.. a skill to teach students how to write an ad online .. because it is one of marketing content .. live video is also one of marketing content ..".

Quote from lecturer respondent no.9, "We ask students to go out with entrepreneurs ... for example this semester we have a collaboration with FAMA (Federal Agricultural Marketing Authority).. with 7 entrepreneurs .. doing business matching with entrepreneurs ...".

The majority of lecturers' respondents felt that sales activities played an important role in the implementation of entrepreneurship in a polytechnic. This is because practical methods such as sales activities actually help students in entrepreneurship with the goal of applying holistic entrepreneurship in polytechnics. In addition, the lecturers also stated in theory that the business plan helps a lot before doing business, especially in finance and marketing. In addition, lecturers need to master business planning so that students can learn how to make a good and effective business plans.

\subsection{Elements of Environment}

According to the analysis, overall respondents of the interview responded positively to the entrepreneurial environment in the application of entrepreneurship and the variety of opinions and views received by the researchers in the interview. Table 4 below provides a brief overview of the results of the interview conducted in conjunction with the lecturers in polytechnics to identify elements of the entrepreneurial environment in the application of entrepreneurship. 
Table 4. Summary of interview results for environmental elements

\begin{tabular}{|c|c|c|c|c|c|c|c|c|c|c|}
\hline \multirow{2}{*}{ Themes } & \multicolumn{10}{|c|}{ Lecturer Respondent } \\
\hline & $\mathrm{P} 1$ & P2 & P3 & P4 & P5 & P6 & P7 & P8 & P9 & P10 \\
\hline Digital Marketing & $\sqrt{ }$ & & & & & $\sqrt{ }$ & & & & $\sqrt{ }$ \\
\hline Product Market & & $\sqrt{ }$ & & & & & & & & \\
\hline Communication Network & & $\sqrt{ }$ & & & & & & $\sqrt{ }$ & & \\
\hline Entrepreneurship Development & & & $\sqrt{ }$ & & & & & & & \\
\hline Entrepreneurial Diversity & & & & $\sqrt{ }$ & & & & & & \\
\hline Interest & & & & & $\sqrt{ }$ & & $\sqrt{ }$ & & & \\
\hline Community Service & & & & & & & & & $\sqrt{ }$ & \\
\hline Online Network & $\sqrt{ }$ & & & $\sqrt{ }$ & & & & & & \\
\hline Democracy & & $\sqrt{ }$ & & & & & & & & \\
\hline Sales & & & $\sqrt{ }$ & & & $\sqrt{ }$ & $\sqrt{ }$ & $\sqrt{ }$ & & $\sqrt{ }$ \\
\hline Tour & & & $\sqrt{ }$ & & $\sqrt{ }$ & & & & $\sqrt{ }$ & \\
\hline Business Space & $\sqrt{ }$ & & & & & & & & $\sqrt{ }$ & $\sqrt{ }$ \\
\hline Culture & & $\sqrt{ }$ & & & & & & & & \\
\hline Consciousness & & & $\sqrt{ }$ & & & & & & & \\
\hline Mind & & & & $\sqrt{ }$ & & & & & & \\
\hline Cooperation and Support & & & & & $\sqrt{ }$ & $\sqrt{ }$ & $\sqrt{ }$ & $\sqrt{ }$ & & $\sqrt{ }$ \\
\hline
\end{tabular}

Below is a selection of lecturer answers which contain the majority of the required environmental elements.

Quote from respondent lecturer no.7, "This conducive environment should have a space that places students for their product.. this place is vendor ready.. the vendor is more on the student rental site, the student is on their product .. and the vendor will just come to quote the result. now we want a big site. This is the place for students to do entrepreneurship .. every Wednesday there is an entrepreneurial day ... practical for the subject of DPB2012 .. for students to apply what they have learned in theory class .. ".

Quote from respondent lecturer no.5, "Getting cooperation from top to bottom.. getting moral support. students as an example can really expose this entrepreneurial spirit not only when it comes to entrepreneurship.. students understand that entrepreneurship ... entrepreneurship covers all aspects .. in our daily lives ... we have to give proper exposure to students.. It is important to get cooperation from all parties. Collaboration with FAMA.. program myagrosis.. a very important element of entrepreneurship in any educational institution.”.

The majority of entrepreneurship lecturers say that Sales is a key component of the entrepreneurial environment to inculcate entrepreneurship among students. This is due to the fact that sales activities involve students in applying the theory learned in the classroom to practical application when students are directly entrepreneurial and subsequently able to apply entrepreneurial elements to students directly. While the lecturers also expressed their cooperation and support in the implementation of entrepreneurship elements in polytechnics. The cooperation and support from the upper management of polytechnic administration in particular can impact the continuity of all activities undertaken in the polytechnic as well as beyond the polytechnic itself.

\section{Discussions}

The framework for applying the entrepreneurial elements below contains a list of entrepreneurial elements that are important in the field of entrepreneurship. The entrepreneurial element implementation framework is therefore a visual implementation based on the themes generated through the interview process and document analysis. 


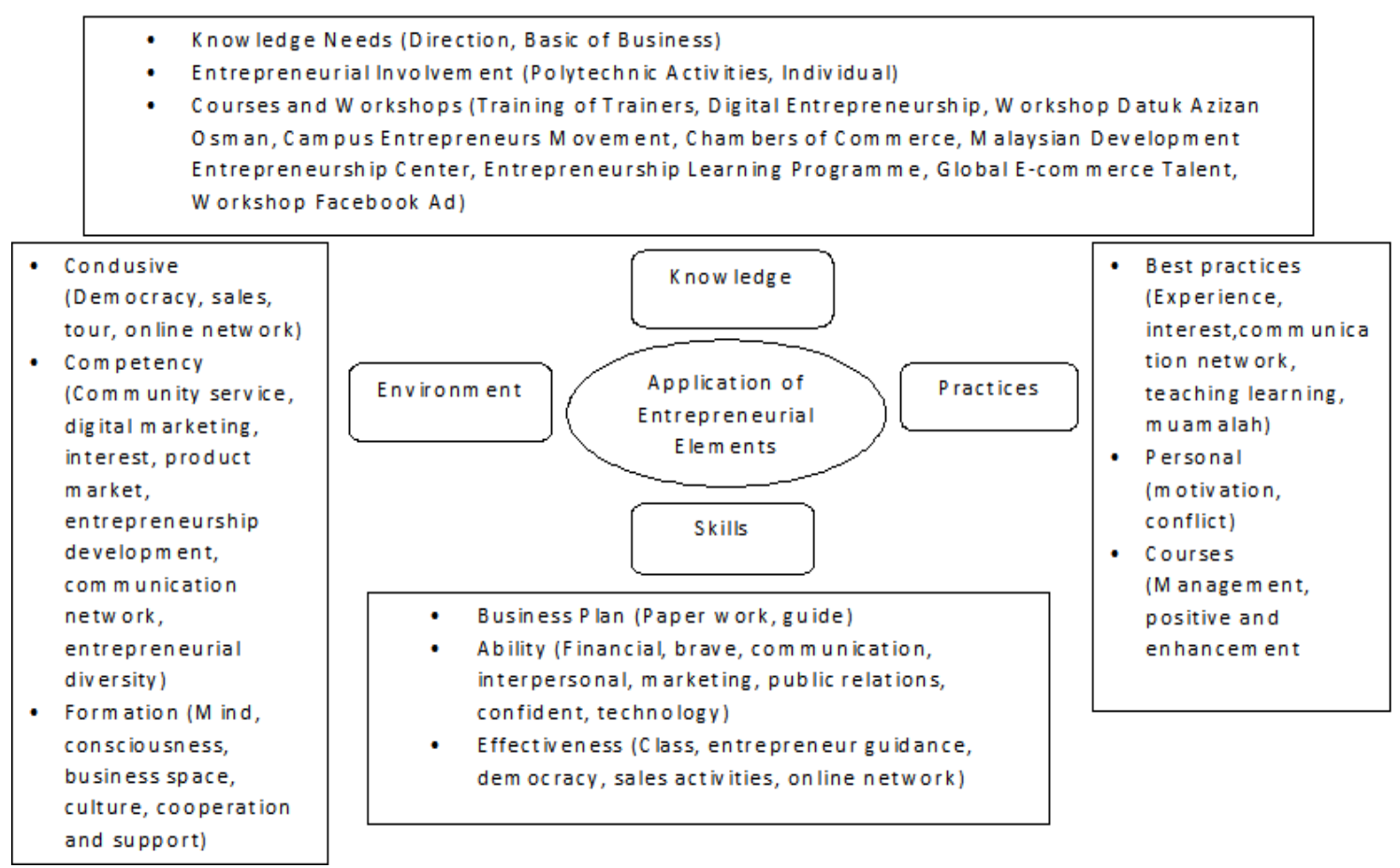

Figure 1. It shows the framework for applying the entrepreneurial element

From the findings of the study, several suggestions have been made to improve and address some of the issues discussed previously.

To facilitate the adoption of entrepreneurship elements in polytechnic Malaysia, the researchers propose the polytechnic education department to increase the special provision for sponsoring lecturers to attend workshops or training on entrepreneurship and business knowledge both in Malaysia and abroad. In addition to enhancing knowledge and skills through such exposure, it can help entrepreneurship faculty strive to better themselves in the light of research that shows entrepreneurship lecturers in Malaysian polytechnics have high levels of practice, knowledge, skills and also the environment.

The polytechnic management also should provide prudent injections and consulting services to lecturers involved in entrepreneurship in Malaysian polytechnics. This is because all the support and encouragement from the management itself can lift the spirit of these lecturers in the field of entrepreneurship.

Further research for this study could be carried out in the future such as studies on lecturers in the implementation of entrepreneurship in polytechnics and studies of the effectiveness of entrepreneurial science among lecturers as well as examining the relationship between the practice, knowledge and skills of a lecturer with the techniques of delivering entrepreneurship knowledge.

As a result, rapid development has led the education system to change with the current and the latest. Demand for a stand-alone workforce that opens a business and has added value as entrepreneurial skills becomes increasingly important. Entrepreneurship is thus a phenomenon that leads to the creation of job opportunities that involve business. Therefore, the guidance and advice of the lecturers on entrepreneurship should be further enhanced so that students can inculcate an interest in entrepreneurship. This is why entrepreneurship applications are so important among polytechnic lecturers to produce polytechnic students who are entrepreneurial. This importance is seen as a catalyst and a catalyst for the production of high quality graduates. In general, this chapter discusses the findings of the study in more detail with the support of previous opinions and studies. This discussion concludes with a follow-up study proposal to improve this study.

Complete infrastructure and a conducive polytechnic environment suited with the teaching and learning methods for the application of entrepreneurial elements should be constantly refined from time to time. Learning will be most effective if supported by adequate and usable facilities. This indirectly helps boost the spirit of entrepreneurship in the field of entrepreneurship. Therefore, the availability of this versatile and comprehensive facility will help polytechnic lecturers prepare for the challenge of applying the entrepreneurial element in the future.

\section{REFERENCES}

[1] Solesvik, (2013) 'Entrepreneurial motivations and intentions: investigating the role of education major’. Vol.55 Issue: 3 , pp 253-271

[2] Nor Aishah Buang, Zulfaka Ishak, Noreen Ismail, dan Lilia 
Abd, Halim. (2014). Pemikiran Sains Keusahawanan Guru-Guru Sains MRSM. Jurnal Kepimpinan Pendidikan, 1(1), 53-64.

[3] Shane and Venkataraman(2013). The Promise of Entrepreneurship as a field of study. The Academy of Management Review, 25 (1).

[4] Sewell and Pool (2007). The key to employability: Developing a practical model of graduate employability. ResearchGate: Article in Education and Training, 49(4):277-289.

[5] Runco, M.A. (2003). 'Creativity, Cognition and Their Educational Implications'. Dalam Houtz, J. (Eds). The Educational Psychology of Creativity (ms. 25-56). New Jersey: Hampton Press.

[6] Syed Zamberi Ahmad (2013). The need for inclusion of entrepreneurship education in Malaysia lower and higher learning institutions. ResearchGate: Article in Education and Training, 55(2).

[7] Mohani, A., Hashanah, I., Haslina, H., Juliana, J., (2008), “SMEs and halal certification”, ECER Regional Conference 2008, UiTM Kelantan

[8] Zafir Mohd Makhbul dan Fazilah Mohamad Hasun. (2003). Siri Pengurusan dan Pentadbiran Utusan: Mengurus Sumber Manusia. Edisi Pertama. Kuala Lumpur: Utusan Publications \& Distributors Sdn Bhd. 203-209.

[9] Kolakowski (2016). The main currents of Marxism. Journal of Education Culture and Society. 4-5.

[10] Muhammad et al, (2017) Determinants of entrepreneurial intentions: An institutional embeddedness perspective. Journal of Small Business and Entrepreneurship . Volume 30, 2018- Issue 2, Pages 139-156.

[11] Cresswell, J.W., and Plano Clark, V.L., (2011). 'Designing and conducting mixed methods research (2nd ed.). Thousand Oaks, CA: Sage.

[12] Sekaran, Uma. (1992). 'Research methods for Business: A skill building approach. New York: Wiley.

[13] Noraini Idris (2010). Penyelidikan dalam pendidikan. Kuala Lumpur: McGraw Hill Education.

[14] Stangor, C. (2011). 'Research methods for the behavioural sciences. Boston: Houghton Mifflin Starko.

[15] Juliza Elide Binti Jumelan. (2014). Penguasaan Kemahiran Insaniah Pelajar Dalam Penglibatan Aktivit Kokurikulum Badan Beruniform Di UHTM. Fakulti Pendidikan Teknikal Dan Vokaisonal. Universiti Tun Hussein Onn Malaysia.

[16] Hair, Lawrence Robinson, Jeanne Segal, Melinda Smith. (2017). Effective Communication. Improving Communication Skills in Your Work and Personal Relationships. Helpguide.Org

[17] Mohd. Salleh Hj. Din dan Gibb, A. A. (1990). Entrepreneurship education: An innovative approach. Working Paper presented to The International Conference on Small and Medium Scale Enterprise, Langkawi, Malaysia.

[18] Mohd Hafeez Al-Amin Bin Adul Wahab. (2013). Penerapan Kemahiran Keusahawanan Dalam Kalangan Pelajar Bidang
Kejuruteraan Mekanikal Di UHTM. Fakulti Pendidikan Teknikal Dan Vokasional. Universiti Tun Hussein Onn Malaysia.

[19] Dam, K.V; Schipper, M dan Runhaar, P. (2010) 'Developing a competency based framework for teachers' entrepreneurial behavior. Teaching and teacher education 26 : 965-971. Netherland. www.elsevier.com/locate/tate

[20] Hair, JF, Bush, RP and Ortinau, DJ. (2003) Marketing research: Within a changing information environment, 2nd edn. McGraw-Hill/Irwin, New York.

[21] Mok Soon Sang. (2002). Pendidikan di Malaysia untuk Kursus Diploma Pengurusan Semester 1. Kuala Lumpur: Kumpulan Budiman Sdn. Bhd.

[22] Nabilah, A. B. (2011). Sejauhmana elemen-elemen pengajaran guru mengikut modul pentaksiran dalam sesi amali. Persidangan Kebangsaan Penyelidikan dan Inovasi dalam Pendidikan dan Latihan Teknik dan Vokasional, 1-11.

[23] Husaini Muhammad dan Haron Khairul Anuar. (2008). Kemahiran Keusahawanan: Satu Kajian Analisis Buku-buku Teks. Seminar Kebangsaan Kemahiran Insaniah dan Kesejahteraan Sosial. Melaka.

[24] Notoatmodjo, S. (2005). Metodologi Penelitian Kesehatan. Jakarta: Pineka Cipta.

[25] Shahrin, H. dan Siti Hasmah, M. (2011). Faktor penghalang penerapan ciri keusahawanan dalam pengajaran dan pembelajaran di sekolah mengikut perspektif guru. Universiti Teknologi Malaysia.

[26] Siti Normala, J. (2011). Tahap pengetahuan terhadap pendidikan keusahawanan dalam kalangan usahawan di Pertubuhan Peladang kawasan Johor Bahru Timur. Universiti Teknologi Malaysia.

[27] Ryan. (1980). 'Looking into Teaching: An Introduction to American Education'. In R. Jusoh, Effects of teachers readiness in teaching and learning of entrepreneurship education in primary schools.

[28] Hasliza Zaman. (2002) Persepsi Guru-guru KPLI yang mengikuti Kursus Diploma Pendidikan Kemahiran Hidup di Maktab tentang Kesediaan mereka mengajar Kemahiran Hidup (Teras). Projek Sarjana Muda.

[29] Faoite, D. D., Henry, C., Johnston, K. Dan Sijde, P. V. (2003). 'Education and training for entrepreneurs: A consideration of initiatives in Ireland and The Netherlands. Journal Education and Training. 45(8/9): 430-438.

[30] Syed Zamberi Ahmad (2013). The need for inclusion of entrepreneurship education in Malaysia lower and higher learning institutions. ResearchGate: Article in Education and Training, 55(2).

[31] Burke, V. Dan Collins, D. (2005) 'Optimising the effects of leadership development programmes: A framework for analysing the learning and transfer of leadership skills', Management Decision. Vol.43 Issue: 7/8, pp.975-987.

[32] Syed Jaafar. (2014). Kompetensi guru dalam pengajaran Amali Teknologi Pembinaan di Kolej Vokasional. Thesis of Bachelor Degree, University of Technology Malaysia.

[33] Pelan Tindakan Keusahawanan, Institusi Pendidikan Tinggi. 2016-2020. Accessed on 12 April 2018. 
[34] Van Gelderen, M. (2007). Research based yet action oriented. Developing individual level enterprising competencies. Kertas kerja yang dibentangkan pada $17^{\mathrm{th}}$ global conference - internationalizing entrepreneurship education and training. Gdarsk: Poland.

[35] Yahya, N. F. (2004). Persepsi pelajar terhadap keberkesanan pengajaran guru dalam pengajian keusahawanan: Kajian di Sekolah Menengah Teknik Alor Setar, Kedah. Kolej Universiti Tun Hussein Onn.

[36] Azrilah Abd Aziz, Mohd Saifudin Masodi dan Azami Zaharin (2013). Asas model pengukuran Rasch. Bangi: Penerbitan UKM.
[37] Dam, K.V; Schipper, M dan Runhaar, P. (2010) 'Developing a competency based framework for teachers' entrepreneurial behavior. Teaching and teacher education 26: 965-971. Netherland. www.elsevier.com/locate/tate

[38] Ibrahim, A., Mohamad Shatar, S., Ahmad Tajuddin, O., Mohamed Yaziz, A., Rahmat, W., dan Faudziah, M.D. (2013). Modul Teras Keusahawanan.

[39] Buang, N. A., dan Yap, P. M. (2002) Kesediaan guru-guru perdagangan di Wilayah Persekutuan dari aspek pengetahuan, kaedah pengajaran dan sikap terhadap pengajaran subjek pengajian keusahawanan, Jurnal Teknologi, 37(1), 1-16. 